\title{
Serine/Threonine-Protein Kinase PAK 3
}

National Cancer Institute

\section{Source}

National Cancer Institute. Serine/Threonine-Protein Kinase PAK 3. NCI Thesaurus. Code C127851.

Serine/threonine-protein kinase PAK 3 ( $559 \mathrm{aa}, \sim 62 \mathrm{kDa}$ ) is encoded by the human PAK3 gene. This protein is involved in the phosphorylation-dependent modulation of signal transduction. 